\title{
How May the United States Leverage Its FATCA IGA Bilateral Process To Incentivize Good Tax Administrations Among the World of Black Hat and Grey Hat Governments?: A Carrot \& Stick Policy Proposal
}

William Byrnes

Follow this and additional works at: https://scholarlycommons.law.emory.edu/eilr-recent-developments

\section{Recommended Citation}

William Byrnes, How May the United States Leverage Its FATCA IGA Bilateral Process To Incentivize Good Tax Administrations Among the World of Black Hat and Grey Hat Governments?: A Carrot \& Stick Policy Proposal, 31 Emory Int'l L. Rev. Recent Dev. 1033 (2017).

Available at: https://scholarlycommons.law.emory.edu/eilr-recent-developments/13

This Essay is brought to you for free and open access by the Journals at Emory Law Scholarly Commons. It has been accepted for inclusion in Emory International Law Review Recent Developments by an authorized administrator of Emory Law Scholarly Commons. For more information, please contact law-scholarlycommons@emory.edu. 


\title{
HOW MAY THE UNITED STATES LEVERAGE ITS FATCA IGA BILATERAL PROCESS TO INCENTIVIZE GOOD TAX ADMINISTRATIONS AMONG THE WORLD OF BLACK HAT AND GREY HAT GOVERNMENTS?
}

\section{A CARROT \& STICK POLICY PROPOSAL}

\author{
William Byrnes*
}

\section{A Carrot \& Stick Policy Proposal}

This Essay serves as a preliminary narrative to examine the serious challenge of Control Firsters' vision that every jurisdiction should have complete information on all transactions by any taxpayer. ${ }^{1}$ The world has many, potentially a majority, of grey hat and black hat governments and tax administrations. One measure of which governments fall into these categories is Transparency International's corruption index. ${ }^{2}$ Of 167 countries ranked by Transparency International for breadth of corruption from one hundred (very clean) to zero (highly corrupt/failed state), only fifty countries ranked above a score of fifty, and only twelve scored above eighty. ${ }^{3}$ A question that Control Firsters must address is whether it is prudent for taxpayers to trust the

* Executive Professor of Law, Texas A\&M University School of Law; Associate Dean, Special Projects. This paper was presented at Cambridge's 34th Annual Economic Crimes Symposium, Sept 4-11, 2016: "Economic Crime-where does the buck stop? Who is responsible-facilitators, controllers and or their advisers?” A Plenary to Explore the Topics Raised in Richard Gordon and Andrew Morriss' article "Moving Money: International Financial Flows, Taxes, \& Money Laundering” on Saturday, September 10th 1:0013:00. A prior version of this Essay appeared as a blog post on Wolters Kluwer's International Tax Blog. William Byrnes, White, Grey and Black Hat Tax Administrators-A Proposal for a U.S. Carrot and Stick Approach Part I, KLUwer InT'L TAX Blog (Aug. 17, 2016), http://kluwertaxblog.com/2016/08/17/whitegrey-and-black-hat-tax-administrations-a-proposal-for-a-u-s-carrot-stick-approach-part-i-followed-by-acritical-fatca-update/.

1 See Richard Gordon \& Andrew Morriss, Moving Money: International Financial Flows, Taxes, \& Money Laundering, 37 Hastings InT’L \& CoMP. L. REV. 1, 41, 57, 92-93 (2014). The “control first” view (coined by Dr. Andrew Morriss and Dr. Richard Gordon) advocates “illegitimate without strict control." Id. at 4. "'Control first' advocates often begin by neglecting the benefits of free markets, and then overstate the benefits of control while ignoring the costs of those controls.” Id. Dr. Andrew Morriss and Dr. Richard Gordon developed an anti-thesis to "control firsters"-the "Efficient Enterprise" view. Id. The Efficient Enterprise view requires including the benefits and costs of free markets, market abuse, and controls of market abuse, to root out inefficient and wasteful regulation. Id.

2 Table of Results: Corruption Perceptions Index 2015, TRANSPARENCY InT'L, http://www. transparency.org/cpi2015\#results-table (last visited Jan. 26, 2017).

3 Id. 
governments of the 117 countries that scored a fifty or below on Transparency International's corruption index. Quite possibly, the complete information system invoked by Control Firsters encourages, even prolongs, the bad behavior by providing fuel (financial information) to feed the fire of corruption and suppression of rivals.

By leveraging a "carrot-stick" policy tool, the United States has the opportunity to incentivize these bad actors to adopt best tax administration practices by offering reciprocal automatic exchange of information via the Foreign Account Tax Compliance Act (FATCA) Competent Authority Agreements (CAA). ${ }^{4}$ The carrot for foreign governments is that the United States will provide the tax information about their tax residents' assets in the United States via the CAA. FATCA requires that the IRS be provided with information about U.S. taxpayers by foreign financial institutions either directly or via their governments. ${ }^{5}$ The stick will be established by the U.S. Congress adopting a Tax Administration Certification version of the former Presidential Annual Narcotics Certification with its corresponding penalties.

Under the Drug Certification Requirements of the Drug Abuse Act, from 1987-2001, by November 1 of each year, the President designated major illicit drug producing and drug transit countries, known formerly as annual narcotics certification. ${ }^{6}$ The President was then required to withhold fifty percent of U.S. assistance for the designated countries for the fiscal year. ${ }^{7}$ By March 1 of each year, the U.S. Department of State prepared, by country, an assessment of the efforts to suppress the international drug trade and money laundering, published to Congress as the "International Narcotics Control Strategy Report" (INCSR). ${ }^{8}$

By March 1, countries that the President had not yet certified as either fully cooperating in U.S. drug control efforts or that had not taken adequate steps to achieve the 1988 United Nations (U.N.) Drug Convention objectives incurred a ratcheting of U.S. penalties. ${ }^{9}$ The potential sanctions included:

\footnotetext{
4 Gordon \& Morriss, supra note 1, at 41.

5 Id.

6 K. Larry Storrs, Cong. Res. Serv., RL32038, Drug Certification/Designation Procedures FOR ILLICIT NARCOTICS PRODUCING AND TRANSIT COUNTRIES 2 (2003).

7 Id.

8 Foreign Assistance Act of 1961 §489, 22 U.S.C. §2291(j) (1961) (amended 2006). For a list of the annual reports see Narcotics Control Reports, U.S. DEP’T OF STATE, https://www.state.gov/j/inl/rls/nrcrpt/ index.htm (last visited Feb. 9, 2017).

9 STORRs, supra note 6 , at 1.
} 
(1) most foreign assistance and financing of military sales for the decertified country were suspended... ; (2) U.S. representatives were required to vote against loans for the country in the multilateral development banks; and (3) certain trade sanctions, including increased tariffs and denial of preferential trade benefits, could be applied at the President's discretion. ${ }^{10}$

The President held the authority, albeit subject to a Congressional veto by majority vote, to annually waive the application of the sanctions in the national interest. ${ }^{11}$ Otherwise, the imposed sanctions remained in force until the country was subsequently certified. ${ }^{12}$

Black and grey hat actors (commonly referred to as "secrecy jurisdictions") that do not provide this information to the United States are effectively cut off from the U.S. financial markets - the United States imposes the thirty percent Chapter 4 (FATCA) withholding on the gross proceeds of many types of payments, such as for the sale of shares and bonds, and all types of passive income. ${ }^{13}$ Pursuant to this policy proposal, Chapter 4 withholding should be extended to nefarious tax administrations that misuse tax information provided by the United States. Moreover, this proposal calls on Congress to enact legislation establishing a legal requirement that the Treasury annually assess by country tax administration and report to Congress by March $1 .{ }^{14}$ Instead of reinventing the wheel for the methodology of the assessment or undertaking work recently completed, the U.S. Treasury may borrow from the Organisation for Economic Co-operation and Development's (OECD) peer review process for tax information exchange and add to the OECD assessment a new Part B "Protection of Taxpayer Information." Alternatively, the United States should encourage the OECD to adopt a Part B evaluation of protection of taxpayer information, albeit on an annual basis, and then the Treasury could draw from these assessments.

\section{The FATCA Train Has Left the Station}

The United States has a highly successful international financial service industry that is important to the U.S. economy. This is exemplified by, firstly,

10 Id. at 2.

11 Id.

12 Id.

13 For an in-depth analysis of FATCA, see William Byrnes \& Robert J. Munro, Background and Current Status of FATCA, in 4 LEXISNEXIS GUIDE TO FATCA COMPLIANCE 1 (4th ed., 2016).

14 See STORRS, supra note 6, at 1. 
the international financial centers, such as Miami and New York, having over half a trillion dollars of foreign deposits of high net wealth individuals, many of whom experts allege are not tax and exchange control compliant in their home countries. ${ }^{15}$ Secondly, with over 900,000 companies registered in its jurisdiction, Delaware is second to Hong Kong, and ahead of British Virgin Islands in the number of companies incorporated there. ${ }^{16}$ Thirdly, U.S. territories' offshore regimes, like the U.S. Virgin Islands, reduce the effective U.S. corporate and income tax rates below 3.5 percent. $^{17}$

In 2011, 133,297 businesses incorporated in Delaware. ${ }^{18}$ "Delaware has more corporate entities ... than people-945,326 to 897,934."19 These absentee corporate residents account for a quarter of Delaware's total budget, roughly $\$ 860$ million in taxes and fees in $2011 .{ }^{20}$ Moreover, the economic spillover impact for Delaware includes substantial employment and professional fees to Delaware businesses participating in the incorporation and advisory industry. The State of Delaware does not maintain a corporate registry of beneficial owners. ${ }^{21}$

Thus, there has been a lot of noise about the potential "giant sucking sound of foreign direct investment (FDI) exiting the U.S. financial markets, like a swirl through a drain," because of the imposition of FATCA withholding or because the United States provides information to foreign governments. ${ }^{22}$ But

15 Nicholas Nehamas, Miami Banks on Future as a Financial Hub, Miami Herald (Feb. 16, 2015, 2:58 PM), http://www.miamiherald.com/news/local/community/miami-dade/article10468874.html.

16 William Byrnes, Commentary on the Panama Papers Disclosing 14,000 Clients' 214,000 Companies Files: Tax Evasion, Political Corruption, and FIFA Connections, InT’L FIN. L. Prof Blog (Apr. 3, 2016), http://lawprofessors.typepad.com/intfinlaw/2016/04/14000-client-offshore-files-leaked-from-mossack-

fonseca-the-panama-papers-disclosing-details-of-2140.html [hereinafter Byrnes, Commentary on the Panama Papers].

17 Tax Incentives: How Do They Work?, U.S. VIRgIN ISLANDS ECON. DeV. AUTHORITY, http://usvieda.org/start-or-grow-business/edc-tax-incentives/tax-incentives-how-do-they-work (last visited Jan. 26, 2017) (the example ETR is $3.37 \%$ according to the U.S. Virgin Islands). See also WILLIAM H. BYRNES \& Dr. Robert J MunRo, TAX HAVEnS OF THE World (LexisNexis 2016).

18 Leslie Wayne, How Delaware Thrives as a Corporate Tax Haven, N.Y. TIMES (June 30, 2012), http://www.nytimes.com/2012/07/01/business/how-delaware-thrives-as-a-corporate-tax-haven.html.

19 Id.

20 Id.

21 Libby Watson, Why Are There so Many Anonymous Companies in Delaware?, SunLIGHT Found. (Apr. 6, 2016), https://sunlightfoundation.com/blog/2016/04/06/why-are-there-so-many-anonymous-corporations-indelaware/.

22 William Byrnes, White, Grey and Black Hat Tax Administrators-A Proposal for a U.S. Carrot and Stick Approach Part I, KLUwER INT'L TAX BLOG (Aug. 17, 2016), http://kluwertaxblog.com/2016/08/17/ white-grey-and-black-hat-tax-administrations-a-proposal-for-a-u-s-carrot-stick-approach-part-i-followed-by-acritical-fatca-update/ [hereinafter Byrnes, Proposal for U.S. Carrot and Stick Approach Part I]. 
the FDI numbers published by the Bureau of Economic Statistics suggest a different conclusion: "Expenditures by foreign direct investors to acquire, establish, or expand U.S. businesses totaled $\$ 420.7$ billion in 2015, an increase of 68 percent from 2014, when expenditures were \$250.6 billion." ${ }^{23}$ Arguably, the United States may have received more FDI and its financial markets may have grown faster without FATCA. But a suppressed FDI is a price Congress decided it was willing to pay to clamp down on access to the financial information of U.S. taxpayers regardless of location.

\section{The World is Full of Black Hat and Grey Hat Governments and Tax Administrations}

Foreign countries also want to receive financial information about their taxpayers from the United States. For the vast majority of countries, more of their taxpayers' assets are held through the United States than vice versa. "The Protocol amending the Multilateral Convention on Mutual Administrative Assistance in Tax Matters will lead to substantially more transnational identity theft, crime, industrial espionage, financial fraud, and suppression of political opponents and religious or ethnic minorities by authoritarian and corrupt governments, including Russia, China, Colombia, and Nigeria." ${ }^{24}$ The over 200 countries and jurisdictions of the world are led by governments, some of which - when it comes to tax administration-are black hat. ${ }^{25}$ For these purposes, black hat is a government that uses tax administration and the information derived therefrom against the citizens or against foreign competitors. ${ }^{26}$ Tax administrators may selectively use tax information against political rivals (for example, accusations made against Russia ${ }^{27}$ and Venezuela). ${ }^{28}$ Some governments are ridden with criminal gangs (accusations

23 New Foreign Direct Investment in the United States, 2014 and 2015, BUREAU ECON. ANALYSIS (July 13, 2016), http://www.bea.gov/newsreleases/international/fdi/2016/fdi0716.htm.

24 David Burton, Two Little Known Tax Treaties Will Lead to Substantially More Identity Theft, Crime, Industrial Espionage, and Suppression of Political Dissidents, HERITAGE Found. (Dec. 21, 2015), http://www.heritage.org/research/reports/2015/12/two-little-known-tax-treaties-will-lead-to-substantiallymore-identity-theft-crime-industrial-espionage-and-suppression-of-political-dissidents.

25 Byrnes, Proposal for U.S. Carrot and Stick Approach Part I, supra note 22.

26 Id.

27 Masha Gessen, The Wrath of Putin, VANITY FAIR (Apr. 2012), http://www.vanityfair.com/news/ politics/2012/04/vladimir-putin-mikhail-khodorkovsky-russia.

28 Arthur Brice, Venezuela Takes Action Against Critical TV Station, CNN (June 5, 2009, 5:05 PM), http://www.cnn.com/2009/WORLD/americas/06/05/venezuela.tvstation.owner/index.html?_s=PM:WORLD. 
laid against Mexico), ${ }^{29}$ or perhaps the government itself is the criminal gang (for example, accusations against Venezuela). ${ }^{30}$ Some governments are accused of using nefarious means such as theft and espionage to obtain business information about foreign competitors on behalf of national champions. The United States has accused China and China has, in turn, accused the United States. ${ }^{31}$

This Protocol isn't limited to decent places like Canada and the U.S.- - though even if it were, giving so much power to the tax agencies of the world is a bad idea. The Protocol includes wildly corrupt places like Albania and Azerbaijan, dictatorships with aggressive intelligence services and a history of cyber thefts like China and Russia, and lots of places like Kazakhstan and Tunisia, which can't hope to protect the information we send them, even if they don't intentionally misuse it. None of their promises is worth anything. ${ }^{32}$

Some governments are grey hat and do not protect tax information. Grey hat governments lack the capacity to do so because of a lack of resources or a lack of will. ${ }^{33}$ As an example, some countries do not consider tax information confidential and even publish tax information publicly. ${ }^{34}$ For example, grey hat governments may allow tax information to be stolen by cyber criminals. ${ }^{35}$ Grey hat tax administrators pass the information to other government

29 Alfredo Corchado, Drug Cartels Taking Over Government Roles in Parts of Mexico, DALLAs NEws (Apr. 2011), http://www.dallasnews.com/news/texas/2011/04/30/drug-cartels-taking-over-government-rolesin-parts-of-mexico.

30 Philip Sherwell, Venezuela: A Land of Political Killings and Gang Turf Wars, TELEGRAPH (Oct. 11, 2014, 3:05 PM), http://www.telegraph.co.uk/news/worldnews/southamerica/venezuela/11156035/Venezuelaa-land-of-political-killings-and-gang-turf-wars.html.

31 See David Burton, Do You Want Your Private Financial Information Automatically Shared with Russia or China?, DAILY SignAl (July 23, 2014), http://dailysignal.com/2014/07/23/want-private-financialinformation-automatically-shared-russian-chinese-governments/.

32 Ted Bromund, Let's Send Your Tax Forms to China, Heritage Found. (June 2, 2016), http://www.heritage.org/research/commentary/2016/6/lets-send-your-tax-forms-to-china.

33 Byrnes, Proposal for U.S. Carrot and Stick Approach Part I, supra note 22.

34 The United States published tax returns and taxpayer information until 1936 and did not have a law protecting taxpayer information until the Watergate scandal. Mark Berggren, I.R.C. 6103: Let's Get to the Source of the Problem, 74 CHI.-KENT. L. REV. 825, 830-31 (1999). Not all U.S. taxpayer information is confidential. Some states publish state taxpayer information, especially resulting from delinquencies ("name and shame”). Stan Veuger, Named and Shamed, U.S. News \& World REP. (Feb. 19, 2015, 9:00 AM), http://www.usnews.com/opinion/economic-intelligence/2015/02/19/shaming-delinquent-taxpayers-only-getsyou-so-far. Many state property tax authorities publish property roles with property value, assessed tax, and owner's name. See, e.g., Delinquent Taxpayers, WIS. DEP'T OF REvEnUE, https://www.revenue.wi.gov/faqs/ ise/topdelin.html\#list4 (last visited Jan. 26, 2017).

35 Byrnes, Proposal for U.S. Carrot and Stick Approach Part I, supra note 22. 
departments, against the rule for an exchange of information. ${ }^{36}$ Grey hat governments may leak taxpayer information to the press (Japan is accused of using this tactic against U.S. taxpayers, with IRS complicity). ${ }^{37}$

In addition to having a legal framework, administrative capacity and processes in place to ensure the confidentiality of the information received, the technical and organizational ability of the participating States to gather information within their own jurisdiction is of utmost importance. This might entail a challenge especially to developing countries and economies in transition. ICC calls upon the UN to provide capacity building and technical assistance, especially to developing countries and economies in transition, by establishing a technical platform-including meetings, seminars and other capacity building or technical assistance events-to allow for swift implementation of AEOI in a secure and cost effective way. ${ }^{38}$

Thomson Reuters Foundation published an interview of Pascal Saint Amans, Director of the OECD's Tax Policy Directorate:

The ability of a developing country to safeguard confidentiality of the financial information it receives from abroad was one challenge that Saint-Amans highlighted.

…

"You have a request from the government on the main opponent in the country. .. in that case, you know there are risks of leakage of the information or misuse of the information," Saint Amans [sic] said.

"Automatic exchange of information is radically different because the bank collects the information and sends it automatically to other countries; therefore the risks of misuse of the information are pretty high.

"That's why you shouldn't engage with automatic exchange of information with a country unless that country has 'Chinese Walls' in

37 Eric Kroh, Ariz. Judge Docks U.S. \$3,000 For Disclosing Taxpayer Info, LAW360 (Feb. 11, 2015, 6:16 PM), http://www.law360.com/articles/620920/ariz-judge-docks-u-s-3-000-for-disclosing-taxpayer-info. See Aloe Vera of America, Inc. v. U.S., No. 15-15672, 2015 LEXIS 16605 (D. Ariz. Feb. 11, 2015).

38 Letter from Dr. Christian Kaeser, Chair, Int'l Camber of Commerce Comm'n on Taxation, to Michael Lennard, Chief, U.N. Int'l Tax Cooperation Section (Aug. 29, 2014), http://www.un.org/esa/ffd/tax/ tenthsession/LetterICC_perspectivesTHE.pdf. 
all its procedures to protect the confidentiality of the information,” Saint-Amans added. ${ }^{39}$

In a 2013 article, the Economist pointed to the challenge of managing the potentially vast amount of information received from automatic information requests:

Another problem with automatic exchange is the huge quantities of data it produces. Europe's tax authorities have struggled to stay on top of the information swapped under the directive. An official from a British dependency taking part in the EUSD reportedly complained that some countries which receive encrypted DVDs with client information do not even get round to asking for the decryption key.

A further concern is the risk of misuse of information by corrupt administrations, or rogue government employees, such as the sale of personal financial data to would-be kidnappers. Global automatic exchange is "a developed-world solution for a global economy unsuited to it", argues Geoff Cook of Jersey Finance. Some developing countries lack the administration to deal with it, says Gurbachan Singh, a tax lawyer in Singapore. In places like Indonesia "you may have a tax officer but not a proper tax office." 40

The Financial Transparency Coalition argues not to require small countries to collect and share information because these do not have staff capacity, financial resources, or systems in place. However, these countries want to receive tax information from the developed economies under the guise that additional tax collections will allow the capacity building necessary to offer developed economy protections and create required data collection systems. The Financial Transparency Coalition states in an article:

While this requirement may sound sensible, the reciprocity clause is problematic for some developing countries that don't have the technological capacity or the staff to compile the information. Often, an entire country may have just one or two employees devoted to international tax issues. Sub-Saharan Africa, for example, would

39 Luke Balleny, Developing Countries Not Ready to Join Tax Evasion Crackdown-OECD, THOMSON REUTERS FOUND. (May 26, 2014, 9:15 A.M.), http://news.trust.org//item/20140526065643-2fhq7/.

40 Automatic Response: The Way to Make Exchange of Tax Information Work, ECONOMIST (Feb. 16, 2013, 4:06 PM), http://www.economist.com/news/special-report/21571561-way-make-exchange-tax-informationwork-automatic-response. 
need to add roughly 650,000 tax administrators to reach average global staffing levels. ${ }^{41}$

\section{Four Areas to Assess a Tax Administration's Handling of Information}

Protection of tax information should involve four fundamental areas of concern (and assessment):

(1) Tax information used by a foreign government for political purpose.

(2) Governments that leak confidential tax information, by example to the media or to national competitors, ${ }^{42}$ to gain an advantage against a taxpayer.

(3) Corrupt governments (for example, narco governments) or corrupt government staff (mafia, narco gangs) using information criminally such as for extortion, for seeking protection money and bribery, for kidnapping of taxpayers, and for fraud against taxpayers.

(4) Porous governments unable to protect tax information from electronic hacking.

\section{The United States Must Lead by Example_Admit Failings, Seek Improvement}

The United States is itself no stranger to at least three of the four above concerns for protecting taxpayer information.

Regarding the first concern of tax information being used for political gain, the United States has experienced its share of the IRS being used for political gain by the President's office against opponents. Presidents Kennedy and Nixon are often referred to but by no means exclusively. ${ }^{43}$ Nixon's Watergate scandal led to the U.S. law against disclosure of taxpayer information. ${ }^{44}$ Congress enacted Section 6103 to ensure that tax returns and tax return information must be kept confidential, unless a statutory exception applies. ${ }^{45}$

\footnotetext{
41 Automatic Exchange Of Information, Fin. TRANSPARENCY COALITION, https://financialtransparency. org/issues/automatic-tax-information-exchange/ (last visited Jan. 26, 2017).

42 National champions may leverage country-by-country reporting information of a foreign (U.S.) competitor to deconstruct the competitor's profit margins, operating costs, and its supply chain.

43 Nicholas M. Horrock, Senate Unit Finds Tax Data Misuse by F.B.I. and C.I.A, N.Y. TIMES (Oct. 3, 1975), http://www.nytimes.com/1975/10/03/archives/senate-unit-finds-tax-data-misuse-by-fbi-and-cia-revenueservice.html?_r=0.

44 See Berggren, supra note 34.

4526 U.S.C. § 6103 (1974).
} 
Section 6103 "was enacted in response to the use of tax return information for political purposes revealed during Watergate." 46

Several media outlets reported that in 2010, an employee of the state of Delaware with access to state residents' federal tax records accessed a Senatorial candidate's records. ${ }^{47}$ The employee discovered a federal tax lien attaching to property of the candidate (reported as an erroneous lien) and leaked this information to the press in an attempt to embarrass her. ${ }^{48}$

Regarding the second concern, in 2015, after more than fifteen years of litigation, a federal court determined that the IRS, with respect to a transfer pricing audit of a U.S. taxpayer, knowingly provided false information concerning alleged tax evasion to a Japanese tax authority. ${ }^{49}$ The foreign authority leaked the alleged tax evasion to the local media, and the taxpayer's business in that country suffered accordingly. ${ }^{50}$ The taxpayer alleged that the IRS knew or should have known that the foreign tax authority regularly leaked taxpayer information to the media. ${ }^{51}$

Regarding the fourth concern, from January 1, 2014 to May 21, 2015, cybercriminals allegedly accessed tax account information of potentially 620,931 taxpayers and those cybercriminals were successful in obtaining access to 355,262 of those taxpayers' accounts. ${ }^{52}$

The U.S. Treasury has far superior funding, resources, and will relative to most of the world's tax administrations to address these concerns. Thus, in the best of circumstances if these concerns materialize in the United States, their effects will be worse if they materialize in foreign countries.

46 Rueckert v. Internal Revenue Serv., 775 F.2d 208, 210 (7th Cir. 1985).

47 Ben Wolfgang \& Dave Boyer, Former GOP Senate Candidate Christine O'Donnell Told Her Tax Records Were Breached, WASH. TIMES (July 17, 2013), http://www.washingtontimes.com/news/2013/jul/17/ former-gop-senate-candidate-christine-odonnell-tol/.

48 Id.

49 Aloe Vera of America et al. v. U.S., No. 15-15672, 2015 LEXIS 16605 (D. Ariz. Feb. 11, 2015); Kroh, supra note 37.

50 Id.

51 Id.

52 Treasury Inspector Gen. fOR TAX Admin., TIGTA-2016-40-037, The InTernal RevenUe Service Did Not IDENTIFy AND Assist All Individuals Potentially AfFected By the Get Transcript APPLICATION DATA BREACH (2016). 


\section{U.S. Reciprocity For IGA Countries?}

In response to the enactment of FATCA and other jurisdictions' interest in facilitating and participating in the exchange of financial account information, the U.S. government entered into a number of bilateral IGAs that set the groundwork for cooperation between the jurisdictions in this area. ${ }^{53}$ Certain IGAs not only enable the IRS to receive this information from Foreign Financial Institutions, but enable more efficient exchange by allowing a foreign jurisdiction tax administration to gather the specified information and provide it to the IRS. ${ }^{54}$ And some IGAs also require the IRS to reciprocally exchange certain information about accounts maintained by residents of foreign jurisdictions in U.S. financial institutions with their jurisdictions' tax authorities. Under these reciprocal IGAs, the first exchange had to take place by September 30, 2015 giving the IRS a deadline to put in place a process to facilitate this data exchange. ${ }^{55}$

The information now available provides the United States and partner jurisdictions an improved means of verifying the tax compliance of taxpayers using offshore banking and investment facilities, and improves detection of those who may attempt to evade reporting the existence of offshore accounts and the income attributable to those accounts. The following is a list of countries of residence for which the reporting requirement applies:

\begin{tabular}{|l|l|l|}
\hline 1. Antigua \& Barbuda & 31. Greece & $\begin{array}{l}\text { 61. Netherlands island territories: } \\
\text { Bonaire, Saba, and St. Eustatius }\end{array}$ \\
\hline 2. Aruba & 32. Grenada & 62. New Zealand \\
\hline 3. Australia & 33. Guernsey & 63. Norway \\
\hline 4. Austria & 34. Guyana & 64. Pakistan \\
\hline 5. Azerbaijan & 35. Honduras & 65. Panama \\
\hline 6. Bangladesh & 36. Hong Kong & 66. Peru \\
\hline 7. Barbados & 37. Hungary & 67. Philippines \\
\hline 8. Belgium & 38. Iceland & 68. Poland \\
\hline 9. Bermuda & 39. India & 69. Portugal \\
\hline 10. Brazil & 40. Indonesia & 70. Romania \\
\hline 11. British Virgin Islands & 41. Ireland & 71. Russian Federation \\
\hline 12. Bulgaria & 42. Isle of Man & 72. Slovak Republic \\
\hline
\end{tabular}

53 I.R.S. News Release IR-2015-111 (Oct. 2, 2015).

54 Id.

55 Id. 


\begin{tabular}{|l|l|l|}
\hline 13. Canada & 43. Israel & 73. Slovenia \\
\hline 14. Cayman Islands & 44. Italy & 74. South Africa \\
\hline 15. China & 45. Jamaica & 75. Spain \\
\hline 16. Colombia & 46. Japan & 76. Sri Lanka \\
\hline 17. Costa Rica & 47. Jersey & 77. St. Maarten (Dutch part) \\
\hline 18. Croatia & 48. Kazakhstan & 78. Sweden \\
\hline 19. Curacao & 49. Korea (South) & 79. Switzerland \\
\hline 20. Cyprus & 50. Latvia & 80. Thailand \\
\hline 21. Czech Republic & 51. Liechtenstein & 81. Trinidad and Tobago \\
\hline 22. Denmark & 52. Lithuania & 82. Tunisia \\
\hline 23. Dominica & 53. Luxembourg & 83. Turkey \\
\hline 24. Dominican Republic & 54. Malta & 84. Ukraine \\
\hline 25. Egypt & 55. Marshall Islands & 85. United Kingdom \\
\hline 26. Estonia & 56. Mauritius & 86. Venezuela \\
\hline 27. Finland & 57. Mexico & \\
\hline 28. France & 58. Monaco & \\
\hline 29. Germany & 59. Morocco & 60. Netherlands \\
\hline 30. Gibraltar & & \\
\hline
\end{tabular}

The following is a list of countries with which the Treasury has determined that the automatic exchange of deposit interest information is appropriate:

\begin{tabular}{|l|l|}
\hline 1. Australia & 10. Italy \\
\hline 2. Canada & 11. Jersey \\
\hline 3. Denmark & 12. Malta \\
\hline 4. Finland & 13. Mauritius \\
\hline 5. France & 14. Mexico \\
\hline 6. Germany & 15. Netherlands \\
\hline 7. Guernsey & 16. Norway \\
\hline 8. Ireland & 17. Spain \\
\hline 9. Isle of Man & 18. United Kingdom \\
\hline
\end{tabular}

\section{What Has the U.S. Treasury Promised?}

In its implementation of the exchange of bank interest information regulations with foreign governments, the U.S. Treasury promises to assess 
each country with which the United States has a FATCA Intergovernmental Agreement (IGA), Tax Information Exchange Agreement (TIEA), and Double Tax Agreement (DTA). ${ }^{56}$ In that assessment, the Treasury determines whether that country has proper protections and policies in place, and whether those protections and policies are actually enforced, for the tax information sent by the United States to it each year.

Revenue Procedure (Rev. Proc.) 2012-24, entitled "Implementation of Nonresident Alien Deposit Interest Regulations,” states in its preamble:

The purpose of this revenue procedure is to list ... the countries with which the United States has in effect an income tax or other convention or bilateral agreement relating to the exchange of information.... As discussed in the preamble to the regulations, even when such an agreement exists, the Internal Revenue Service (IRS) is not compelled to exchange information, including information collected pursuant to the regulations, if there is concern regarding the use of the information or other factors exist that would make exchange inappropriate. ${ }^{57}$

The May 14, 2012 "Guidance on Reporting Interest Paid to Nonresident Aliens” for the Rev. Proc. 2012-24 states in pertinent part:

Second, consistent with established international standards, all of the information exchange agreements to which the United States is a party require that the information exchanged under the agreement be treated and protected as secret by the foreign government. In addition, information exchange agreements generally prohibit foreign governments from using any information exchanged under such an agreement for any purpose other than the purpose of administering, collecting, and enforcing the taxes covered by the agreement. Accordingly, under these agreements, neither country is permitted to release the information shared under the agreement or use it for any other law enforcement purposes.

Third, consistent with the international standard for information exchange and United States law, the United States will not enter into an information exchange agreement unless the Treasury Department and the IRS are satisfied that the foreign government has strict confidentiality protections. Specifically, prior to entering into an information exchange agreement with another jurisdiction, the Treasury Department and the IRS closely review the foreign 
jurisdiction's legal framework for maintaining the confidentiality of taxpayer information. In order to conclude an information exchange agreement with another country, the Treasury Department and the IRS must be satisfied that the foreign jurisdiction has the necessary legal safeguards in place to protect exchanged information and that adequate penalties apply to any breach of that confidentiality.

Finally, even if an information exchange agreement is in effect, the IRS will not exchange information on deposit interest or otherwise with a country if the IRS determines that the country is not complying with its obligations under the agreement to protect the confidentiality of information and to use the information solely for collecting and enforcing taxes covered by the agreement. The IRS also will not exchange any return information with a country that does not impose tax on the income being reported because the information could not be used for the enforcement of tax laws within that country. ${ }^{58}$

On December 29, 2014, the Treasury updated Rev. Proc. 2012-24, "Implementation of Nonresident Alien Deposit Interest Regulations," with Rev. Proc. 2014-64. ${ }^{59}$ This revenue procedure lists the countries with which the United States has in effect an income tax or other convention or bilateral agreement relating to the exchange of information pursuant to which the United States agrees to provide, as well as receive, information. This revenue procedure also lists, in Section 4, the countries with which the Treasury Department has determined that it is appropriate to have an automatic exchange relationship with respect to the reporting of certain deposit interest paid to nonresident alien individuals on or after January 1, 2013. ${ }^{60}$ In the case of interest aggregating ten dollars or more paid to a nonresident alien individual the payor is required to make an information return on Form 1042-S for the calendar year in which the interest is paid. ${ }^{61}$ The eighteen countries include Australia, Canada, Denmark, Finland, France, Germany, Guernsey, Ireland, Isle of Man, Italy, Jersey, Malta, Mauritius, Mexico, Netherlands, Norway, Spain, and the United Kingdom. ${ }^{62}$

Thus, the Treasury and the IRS have promised that the United States will only engage in reciprocal exchange with foreign jurisdictions that, among other

\footnotetext{
58 T.D. 9584, 2012-20 I.R.B., 77 Fed. Reg. 23391.

59 Rev. Proc. 2014-64, 2014-53 I.R.B.

60 Id. at $\S 4$.

$61 I d$. at $\S 2$.

$62 I d$. at $\S 3$.
} 
requirements, meet the IRS's stringent safeguard, privacy, and technical standards. ${ }^{63}$ Before exchanging with a particular jurisdiction, the United States conducted detailed reviews of that jurisdiction's laws and infrastructure concerning the use and protection of taxpayer data, cyber-security capabilities, as well as its security practices and procedures. ${ }^{64}$ Yet, there is no assurance that IRS systems are secure. Nor is there any indication if the U.S. Treasury would assume financial responsibility should disclosure of taxpayer information to black hat or grey hat governments (or other nefarious actors) cause financial losses or other damages. The U.S. Treasury has established a website "Reporting Unauthorized Disclosure or Misuse of Tax Information Exchanged Under an International Agreement." 65

The IRS announced on October 2, 2015 that it achieved the exchange of financial account information with certain foreign tax administrators. ${ }^{66}$ This was in keeping with a key September 30, 2015 FATCA target date. To have achieved this promise, the IRS must have successfully and timely developed the information system infrastructure, procedures, data use and confidentiality safeguards, and means to access other countries' developments thereof, to protect taxpayer data while facilitating reciprocal automatic exchange of tax information with these eighteen foreign jurisdiction tax administrators that include Mexico. The American Bankers Association Comment Letter to the U.S.-Mexico FATCA IGA states:

By including an automatic exchange provision in the U.S.-Mexico IGA, it is difficult to see how the Treasury can honor its commitment and promise to only provide information to Mexico after it has made a determination (based on unknown factors) that Mexico is complying with its obligations to protect the confidentiality of such information. ${ }^{67}$

The U.S. Congress should extend the State Department's required process to evaluate countries for assistance in the U.S. and global fight against

63 I.R.S. News Release, supra note 53.

64 FATCA - A Status Report, TGS GLOBAL BUs. NeTwORK, http://www.tgs-global.com/4/665/fatca-astatus-report (last visited Jan. 26, 2017).

65 Reporting Unauthorized Disclosure or Misuse of Tax Information Exchanged Under an International Agreement, INTERNAL REVENUE SERV., https://www.irs.gov/businesses/corporations/reporting-unauthorizeddisclosure-or-misuse-of-tax-information-exchanged-under-an-international-agreement (last updated Jan. 26, 2017).

66 I.R.S. News Release, supra note 53.

67 Letter from Frank Keating, President \& Chief Exec. Officer, Am. Bankers Ass’n, to Timothy Geithner, Secretary, U.S. Dep't of the Treasury, et al., (Dec. 12, 2012) http://www.aba.com/Advocacy/ LetterstoCongress/Documents/ABANRALetter-USMexicoIGA121212.pdf. 
narcotics trafficking to also evaluate countries' tax administration for bona fides and protection of information.

\section{OECD Peer Review System for Information Exchange}

The OECD has stressed that its two key streams of work in relation to the new Standard on Automatic Exchange of Information (AEOI) are monitoring its implementation and helping developing countries to benefit from it. With regard to the monitoring, the Global Forum established its AEOI Group, formed in 2013 as a voluntary group and comprising almost sixty Global Forum jurisdictions and three Global Forum observers. ${ }^{68}$ The Group is tasked with creating a mechanism for monitoring and reviewing the implementation of the new standard. ${ }^{69}$

Work commenced in 2014 for the creation of new terms of reference and a new methodology, which allows for Global Forum member and relevant nonmember jurisdictions to be evaluated for the effectiveness of the implementation, including the meeting of confidentiality and data safeguard requirements. These reviews are aimed at ensuring a globally consistent implementation of the standard. According to the outcomes of the Global Forum meeting held in Berlin in October 2014, the Global Forum planned to develop over 2015 the detailed terms of reference and methodology. ${ }^{70}$ As of the Global Forum meeting held in Barbados October 29-30, 2015, the Global Forum completed 215 peer reviews and assigned compliance ratings to eightysix jurisdictions that have undergone Phase 2 reviews. ${ }^{71}$ The Global Forum now has 135 members of which ninety-eight have signed the Convention on Mutual Administrative Assistance in Tax Matters and eighty-three have signed the multilateral competent authority agreement for automatic exchange of information. ${ }^{72}$

68 The Role of the Global Forum, ORG. FOR ECON. CO-OPERATION \& DEv., http://www.oecd.org/tax/ automatic-exchange/commitment-and-monitoring-process/role-of-the-global-forum/ (last visited Jan. 26, 2017).

69 Id.

70 Org. for Econ. Co-Operation \& Dev., Global Forum on Transparency and Exchange of INFORMATION FOR TAX PURPOSES-STATEMENT OF OUTCOMES 28-29 OCtOBER 2014 at 3, http://www.oecd.org/tax/transparency/statement-of-outcomes-gfberlin.pdf.

71 Jurisdictions That Have Undergone Only Phase 1 Reviews, ORG. FOR ECON. Co-OPERATIOn \& DEV., (July 26, 2016), http://www.oecd.org/tax/transparency/GFratings.pdf.

72 Chengdu, Org. for Econ. Co-Operation \& Dev., SECretary General Report to G20 Finance MiNISTERS (2016), http://www.oecd.org/tax/oecd-secretary-general-tax-report-g20-finance-ministers-july2016.pdf. 
The OECD and G20 members agreed that, via peer review, jurisdictions would be assessed against three objective criteria: implementation of the Exchange of Information on Request (EOIR) standard, the implementation of the AEOI standard, and joining the multilateral Convention on Mutual Administrative Assistance in Tax Matters (multilateral Convention). To be marked "cooperative" in terms of tax transparency, a jurisdiction must meet two of these three criteria. ${ }^{73}$

The Global Forum announced that it would start a second round of peer reviews from July 2016 under additional terms of reference. ${ }^{74}$ These additional terms include an assessment criterion of the availability of beneficial ownership information set out by the Financial Action Task Force standard as well as its access by the tax authorities whereas previously the criterion only referred to the availability of legal ownership and identity information of legal entities and arrangements. ${ }^{75}$ What is missing is a criterion requiring the assessment of a government's protection and limited use of information received by exchange.

73 The USA will Avoid Being Cast as a Tax Haven-But That Brings the Whole Process Into Disrepute, TAX RES. UK (July 22, 2016), http://www.taxresearch.org.uk/Blog/2016/07/22/the-usa-will-avoid-being-casta-a-tax-haven-but-that-brings-the-whole-process-into-disrepute/.

74 Exchange of Information on Request, ORG. FOR ECON. CO-OPERATION \& DEV., http://www.oecd.org/ tax/transparency/exchange-of-information-on-request/ (last visited Jan. 26, 2017).

75 Id. 